\title{
Effects of Lexico-syntactic Errors on Teaching Materials: A Study of Textbooks Written by Nigerians
}

\author{
Peace Chinwendu Israel \\ English Unit, National Open University of Nigeria, Lagos, Nigeria \\ E-mail: Peacenwendu1@yahoo.co.uk
}

Received: 05-11- 2013

Accepted: 27-12-2013

Published: 31-01-2014

doi:10.7575/aiac.ijels.v.2n.1p.75

URL: http://dx.doi.org/10.7575/aiac.ijels.v.2n.1p.75

\begin{abstract}
This study examined lexico-syntactic errors in selected textbooks written by Nigerians. Our focus was on the educated bilinguals (acrolect) who acquired their primary, secondary and tertiary education in Nigeria and the selected textbooks were textbooks published by Vanity Publishers/Press. The participants (authors) cut across the three major ethnic groups in Nigeria - Hausa, Igbo and Yoruba and the selection of the textbooks covered the major disciplines of study. We adopted the descriptive research design and specifically employed the survey method to accomplish the purpose of our exploratory research. The lexico-syntactic errors in the selected textbooks were identified and classified into various categories. These errors were not different from those identified over the years in students' essays and exam scripts. This buttressed our argument that students are merely the conveyor belt of errors contained in the teaching material and that we can analyse the students' lexico-syntactic errors in tandem with errors contained in the material used in teaching.
\end{abstract}

Keywords: Nigerian English; English as a Second Language; Error Analysis

\section{Introduction}

\subsection{Background to the Study}

Whenever a language functions as a borrowed second language, problems of usage are bound to arise. This is because when a language moves out of its original speech community, it is inevitable to have some super-imposed linguistic features and friction resulting from the meeting of two systems and cultural patterns. In a country like Nigeria, such problems take different forms and are usually traceable to linguistic, educational, social, political and historical factors.

Educational constraints include the poor quality of teaching and teaching material, and the non-availability of qualified teachers. Books, which are veritable teaching material, play a vital role in individual and national development. They are a dependable source of growth for developing countries towards industrialization. Since the time that man started writing, books have come to be accepted as an indispensable foundation upon which any sound educational development is built; yet, not all societies take the issue of quality of books in their schools seriously. Ker (2009) notes that Nigeria, being one of such societies, has experienced a negative impact on the quality and quantity of education given to its citizens.

The contact situation between English and the numerous indigenous Nigerian languages (with all its sociolinguistic implications, including interference and the resulting bilingualism/multilingualism) played a crucial role in shaping the quality of books published in Nigeria. Moreover, when the English language (being outside its native environment) continues to be taught by non-native speakers, who were themselves taught by non-native speakers, there is bound to be deviations from the norm in usage (Olagoke, 1981) which can easily be reflected in the quality of textbooks in circulation.

Furthermore, at school the learner is taught mostly by teachers to whom the language is also a second language and who, therefore, have not quite completely escaped the linguistic constraints such as a limited vocabulary range in their repertoire; a certain degree of insensitivity to the different levels of the language - formal, informal, familiar, colloquial; and the inherent syntactic, phonological and semantic peculiarities of the target language itself. And as it is theoretically unattainable for a learner to rise above the general level of competence of his own teacher, the problem becomes self-compounding since the teachers' own shortcomings are also transferred to the learners in the teaching process in addition to relatively few teachers having to cater for unmanageably outsized classes of learners. Again, the natural language skill development sequence of listening-speaking-reading-writing appears not be acquired in the proper order by the Nigerian speakers/users of English. Hence Adetugbo's (1979) view is that the language Nigerians learn is 'second-hand' in many respects.

These problems easily manifest themselves in the areas of phonology, syntax, lexis and semantics - with ' $\ldots$..syntax and lexis perhaps constituting the areas with the greatest incidence of ... interference' (Okoro, 1980). This is the background against which we undertake this study. 


\title{
1.2 English in Nigeria
}

The beginning of the use of English in Nigeria can be traced back to the early nineteenth century when freed slaves of Nigerian origin returned to Nigeria following the abolition of slave trade. Many of the freed slaves of Nigerian origin had learnt English from abroad. Later, after the colonisation of Nigeria by the British, Nigeria used the language for administration. English then became prominent in the educational system and was used for official purposes. It also became elitist, symbolised by a few privileged Nigerians who were the civil servants and who served as models for indigenes who sought after formal education.

The use of English in Nigeria survived the departure of the colonial administrators as the language of administration. Several years after independence, English has assumed a more important status in Nigeria, and being one of the after effects of colonialism, knowing English has become a yardstick for the measurement of self-worth and selfactualisation. As King-Aribisala (2012) puts it:

\author{
The debilitating effects of colonialism were such that many blacks in \\ the face of the material power of the white colonials, as well as the \\ psychological pressures meted out by colonial administrators and missionaries, \\ suffered self-doubts about their social heritage. Even when \\ political independence was achieved, black nations realised that in effect \\ they had no real power to change their lot because they had no economic \\ power; being dependent on their former European colonizers even in \\ language use.
}

English does not only serve as a medium of social and inter-ethnic communication, it also serves as a national language and it is used to conduct legislative, executive and judicial functions at the three tiers of local, state and federal government levels.

In a situation where English is in contact with many local languages, and where English is a second language, it is to be expected that the kind of English found will be different from the varieties of English spoken in countries where English is native. The point about English in Nigeria is not just that it is different from British English or American English; it is rather that there are several varieties of English 'ranging from something very near standard English to the patois of the market place'(Grieve, 1966). This eventually prompted a variety of English known as 'Nigerian English'. This variety of English is meant to serve as a term which is to cover the diverse kinds of peculiarities which is prominent at the lexical, syntactic, phonological and semantic levels of the English language that has served various functions in Nigeria. It enjoys unequivocal acceptance as a legitimate variety of the world Englishes and also occupies a respectable place among the "New Englishes" (cf. Spencer, (1971); Ubahakwe, (1979); Pride, (1982); Kachru, (1982); Platt et al, (1984); Jowitt, (1991); Bamgbose et al, (1995); Awonusi \& Babalola, (2004); Dadzie \& Awonusi, (2004), for example).

\section{Significance of the Study}

In Nigeria, while the authors' subject competence is usually not in doubt, the linguistic competence of a good number of their textbooks is largely in doubt. But the ability of writers to effectively communicate facts of knowledge in the respective subjects to their readers depends on how effective they are able to handle the language. Authors take risks when they push language to its limits. If they break too many rules, they can fall over the edge of language into unintelligibility (Crystal, 1997). It is therefore a worthwhile effort to undertake an insightful analysis of the language of textbooks written by Nigerian authors in a selection of disciplines with a view to characterizing these errors and assessing their effect on the text-meaning. A study of this nature has become relevant in this age of vanity publishing in Nigeria, when most books are published, not because they have been put through a rigorous editorial process and indeed found publishable, but because the writers can afford to pay the full cost of publication to publishers who publish only for profit and do not care about integrity. Emphasising the importance of the correctness of language usage, TimothyAsobele (2007) cites the $6^{\text {th }}$ Century Chinese philosopher, Confucius's answer, on what he would do first if obliged to administer a country:

It would certainly be to correct language. If language is not correct, then what is said is not what is meant; if what is said is not what is meant, then what ought to be done remains undone; if this remains undone, morals and art deteriorate; if morals and art deteriorate, justice will go astray; if justice goes astray, the people will stand about in helpless confusion. Hence there must be no arbitrariness in what is said. This matters above everything.

Although there are reported studies on grammatical errors found in the language of Nigerian users of English, such as Okoro (1980) and Olagoke (1981), to our knowledge, available literature shows that none has been based on the errors found in textbooks written by Nigerians. Therefore, this new area would provide fresh insights into the language use of 
the Nigerian textbook authors. The outcome of this research would have far reaching effects on grammatical description, English Language teaching and learning, language use in education generally, training, English Language course book writing, and research orientation in error identification and analysis, apart from enriching the body of knowledge in error as a linguistic phenomenon.

\section{Theoretical Framework}

This research is predicated upon the framework of Error Analysis (Corder, 1967, Richards, 1971b, Dulay and Burt 1974). The concept, Error Analysis, has the proven capacity to adequately handle natural language data (Darus 2009:487) such as that which is dealt with here. It is also an effective method of exhaustively accounting for many of the errors in a corpus in any identified level of language analysis, here the levels of lexis and syntax (cf. Chomsky 1957).

\section{Methodology}

\subsection{Research design}

In this study, we carried out a content analysis of the selected textbooks written by Nigerian authors. Berelson (1952) defines Content Analysis as 'a research technique for the objective, systematic, and quantitative description of manifest content of communications'. Content analysis is a research tool focused on the actual content and internal features of media and it "reflects a close relationship with socio- and psycholinguistics..." (ibid). It is used to determine the presence of certain words, concepts, themes, phrases, characters, or sentences within texts or sets of texts and to quantify this presence in an objective manner.

Further more, we equally adopted the descriptive research design. This is because our research falls under applied linguistics which aims at identifying and characterizing linguistic errors in textbooks written and produced in the Nigerian English as a Second Language (ESL) environment. The descriptive research design is concerned with current practices or status and answers the question "what is?" It does this through gaining insight into a situation through observation.

\subsection{Criteria for the Selection of Textbook}

The following criteria were used to select our analysed textbooks. We accessed the information about the books and the author from the blurbs of the selected textbooks. It is worthy to note here that all the selected authors (as at the time of this selection) are teachers in tertiary institutions in Nigeria.

1. The textbooks were written by Nigerians.

2. The authors are at least graduates from a Nigerian university or polytechnic.

3. The authors acquired their primary, secondary and tertiary education in Nigeria.

4. The authors are graduates in the field they wrote on.

5. The textbooks are written for academic purposes.

6. The textbooks are used for tertiary education.

7. The textbooks were published locally.

8. The textbooks were not published by the established publishing houses such as Longman, Macmillan and Heinemann.

9. The textbooks were published between the year 1990 and the year 2010 .

\subsection{Nature and Sources of Data}

The choice of textbooks for this study was by motivation through stratified sampling technique and the textbooks are six in number. They are:

- A Handbook on the Use of English for Tertiary Institutions by Abiola Akinkugbe \& Abla Ero-Philips, Published by Mesi-Kaka (Nig.) Co. Shomolu, Lagos, Nigeria in 1996. (Textbook 1, Arts Sources)

- Library Education: a Handbook on Library Use by Molokwu Ugochi E., published by T-Excel Publishers, 14, Awofola Street, Akoka, Lagos, Nigeria in 2006. (Textbook 3, Education Sources)

- Basic Biology: a Didactic Approach by Jeff Odunukwe published by Academic Publishing Company, 33 Edinburgh Road, Enugu, Nigeria in 2004. (Textbook 5, Science Sources)

The data extracted from these textbooks is authentic, corpus-based and empirical in nature.

\subsection{Study Population and Sample}

All textbooks written by Nigerians constitute the entire population of the study. The target population (the population our findings and conclusions directly applied to) consists of those textbooks by some Nigerian graduates that were published by those publishing houses which publish for money and not for integrity otherwise known as vanity publishers/press. The sampling technique adopted in this study was stratified sampling. This sample technique which ensures the representation of all strata of the population was adopted for choosing the representative samples. Three textbooks, representing major fields of study - Art, Education and Sciences, were selected on the further consideration 
of factors such as availability and affordability. The choice of the authors also was done to ensure the representation of the major ethnic groups in Nigeria - Hausa, Igbo and Yoruba.

The textbooks we studied were limited to three to facilitate an in-depth analysis, and this has enabled us to account for the errors encountered adequately.

\subsection{Procedure for Data Collection}

To ensure a systematic spread throughout each textbook, our data was extracted from:

(i) the first page of each chapter;

(ii) a page from the middle of each chapter; and

(ii) a page at the end of each chapter.

\subsection{Procedure for Data Presentation and Analysis}

As much as possible, each erroneous item was completely presented in the micro-context of use, namely, the entire sentence in which it occurred. This was done, first, to show the structural relationship between the erroneous item and other items in the sentences, and second, to reveal its full range of meaning so that those erroneous structures that needed to be accounted for in terms of semantic transfer from $\mathrm{L}_{1}$ could be readily recognized as such. The data analysis consisted of structurally analyzing each item. Structures were grouped according to their peculiar characteristics including errors and error types. The characteristics of each group were then analyzed and these characteristics were accounted for linguistically in terms of the violation of identifiable native-English constraints, or in terms of $\mathrm{L}_{1}$ and other notable influences.

\section{Summary of Findings}

The errors we analyzed in this study are grammatical errors. We did not analyze typographical error because this is not our concern. However, the spelling and punctuation errors we identified here are labelled as such and are different from typographical errors because they occurred more than once in the textbooks and so cannot be classified as typographical errors.

\subsection{Finding One}

Essentially, the identified errors are broken down as follows:

Textbook 1 has a total number of 15 chapters. In all, the book contains a total number of 2,899,000 sentences. We investigated a total number of 580 sentences and 46 of those sentences contain errors.

Textbook 2 has 13 chapters. The book contains a total number of 2,351,000 sentences. We investigated 407 sentences and 155 of them contain errors.

Textbook 3 contains 7 chapters and there are a total number of 721 sentences. We investigated 184 sentences and 26 of those sentences contain errors.

Our analysis displays features such as:

\section{(a) Modification}

(i) Noun Head Premodification

This is often characterised by:

- omission of determiners, especially the articles

- superfluous insertion of determiners

- deviation in the sequence of determiners

Omission of determiners and insertion of determiners occur in context where no serious impairment of grammar or meaning is done, but where native English usage would nevertheless not omit or insert the determiners. The insertion and omission of determiners in these contexts are consistent with all the examined authors.

(ii) Noun Head Postmodification

Here, only the relative clause postmodifier showed peculiar characteristics, namely:

- too frequent use of "that" in place of who and which

- also, substitution of "that" for when and where.

The use of the relative pronoun "that" in the place of its counterparts "who" and "which" was again consistent, and occurred quite noticeably in the Business Administration and Sciences textbooks.

\section{(b) Prepositions and Verb Particles}

Three distinct patterns in the use of prepositions and verb particles were revealed, namely:

- the substitution of some other prepositions and particles for the usual one

- the superfluous insertion of prepositions and particles

- the omission of prepositions and particles 
(i) Here, the substitution of some other prepositions for the usual ones occurs in contexts where the substitutes do not impair meaning nor sound outlandish nor appear erroneous generally. Although they may not be used by native speakers of English, their acceptability in such contexts is enhanced by the general lack of selectional-restriction rules (collocation) for pronouns in most contexts of their occurrence.

(ii) The omission of prepositions is not as prominent as substitution, and is in fact almost restricted to the omission of "on" before days of the week, months, years and dates generally - a clear influence of American English particularly noticeable in mass media, internet and Microsoft usage.

(iii) No instances of substitution, insertion or omission of verb particles are justifiable at the acrolectal stage. This is because of the functional duty the verb performs in a sentence. All the examined authors are guilty of this error, and in many cases, meanings are impaired.

\section{(c) Concord}

The following characteristic variations were revealed:

- the frequent use of one ... or the other for one ... or another

- the substitution of the reflexive pronouns themselves, ourselves, yourselves for the reciprocal each other and one another

- the use of "they" often with unspecified antecedents

- the honorific use of "they" for singular antecedents

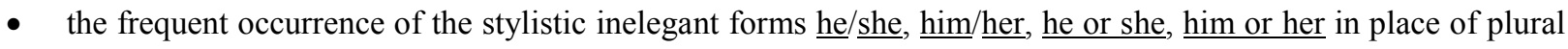
proforms or the generic he or him

The use of the forms he/she, him/her, he or she, him or her in the place of plural proforms or the generic he or him were not treated as errors in this study; although some gender sensitive linguists frown on such usages and regard them as deviant structures or outright errors (Ananda, 2009). The worrying aspect was that the authors were inconsistent with this usage and this was consistent with all the examined authors.

(d) Lexis

The following peculiar characteristics were discovered:

- frequent pluralisation of non-plural forms

- non-pluralisation of plural forms

- coinages, in the form of - independent coinage; acronyms; derivatives; change of word class; reduplication

- confusion of homophones and partial homophones

- Loans in the three categories: (a) those which occur because native English usage has no equivalents for them; (b) those which have equivalent lexical items in English but continue to be used alongside them; (c) and those which occur as qualifiers of other English terms.

Here, coinage, meaning extension without impairment of intelligibility and loans are marked characteristics. Ambiguous words choice which impaired meaning and legitimate English words in the wrong positions e.g. *Be careful not to loose the money. (lose); *Practice compliments theory. (complements) are such errors.

\subsection{Finding Two}

The identified erroneous structures were classified into possible categories.
a. lexical errors
b. errors in the use of function words;
c. errors in sentence structure;
d. errors in concord relations;

After a detailed analysis, these errors were further categorized into the following sub-types based on the violation of grammatical rules with the help of our theoretical framework.

\section{(a) Omission of Determiners before Singular Nouns}

The articles, definite and indefinite, posed a major problem and were omitted before singular nouns.

\section{(b) Inclusion of Redundant Elements/Reduplication}

This feature occurred in three categories -

- those that involve the use of 'etc' after words such as include, such as and e.g.

- those that involve the use of redundant preposition

- those that involve repeating the same thing using another word or expression. 
(c) Restructuring of Collocations

Well known doubles or dyads were altered without any known cause.

(d) Alteration of the Grammatical Property of Collocational Items

This feature occurred in five categories -

- those that involve orthographic (spelling) error

- those that involve concord error

- those that involve the misuse of prepositions and wrong word choice

- those that involve the misuse of the verb (a. using transitive verb intransitively b. using the noun instead of the verb spelling of certain verbs c. using stative verbs dynamically)

- those that involve the pluralisation of non-count nouns

(e) Restructuring of Parallel Sentences

(f) Substitution of Lexical Elements within Collocational Structures

\section{Contributions to Knowledge}

(a) This study, to the best of our knowledge, may be the second on language errors in textbooks written by Nigerian authors apart from Israel's (2012) investigation. Incidentally, errors have never before been accounted for in temporal terms. The frequency of errors found in this study therefore provides empirical evidence of the real problems in education in Nigeria as these relate to writers/teachers' competence in the English language.

(b) This study has examined the characteristics of the elitists' model - acrolect (the acceptable model in characterising Nigerian English: Banjo, 1971a; Adetugbo, 1977; Adeniran, 1979; Akere, 1982; Awonusi, 1985, 2004; Okoro, 1992). The identified characteristics can be arranged and studied as a system. This is a step towards codification of Nigerian English, which is one of the major preoccupations of Nigerian English linguists today. Also, the research has expanded the source of falling standards of English usage in Nigeria by calling attention to the role of authors of textbooks in Nigeria as a potential and more serious reason (cause) for the falling standard.

Many Nigerians have been known to believe that whatever that is written in a book must be the correct usage. Some have been known to even consult textbooks rather than the dictionary for spelling and correct expressions. This study has produced a clear picture that all is not well with books written by some Nigerian authors, as some of them contain errors of different types.

\section{Conclusion}

A research of this nature, unarguably, has its own inevitable constraints. For one thing, the available data, no matter how systematically or painstakingly collected and collated, can never be representative of all the usage possibilities. The welter of data should therefore be seen more as indicators of usage patterns in some teaching materials in circulation than as an exhaustive corpus. Again, the dynamism which is an inherent characteristic of languages, places every language inevitably in a state of influx. On the other hand, grammatical descriptions and the characterisation of language features are by their nature static.

However, this study has helped to expose the knowledge that the students are merely the conveyor belt of lexicosyntactic errors contained in the very teaching material they use in learning. The major syntactic and lexical errors we discovered and analysed are not different from those identified by previous researchers over the years in students' essays and exam scripts - Bamgbose, (1971); Adekunle, (1974); Adeniran, (1979); Adetugbo, (1977, 1979, 1984,); Akere, (2004); Jibril, (1979); Olagoke, (1981); Kujore, (1985); Obilade, (1984); Okoro, (1984, 1992, 2004); Jowitt, (1991). Since the selected authors are teachers and the textbooks are those used in classroom teaching, it then clearly demonstrates that we can analyse the students' lexico-syntactic errors in tandem with such errors contained in the very material used in teaching/learning. Again, we can say that while enormous progress has been made in Nigeria in areas such as technology, science, geoinformatics, politics, fashion, music and movies over the years, not much has been achieved on English language grammar and usage.

\section{References}

Adekunle, M. A.(1974) “The standard Nigerian English in sociolinguistic perspectives” in Journal of Nigerian English Studies Association (JNESA), vol. 6. No.1

Adeniran, A. (1979) "Nigerian elite English as a model of Nigerian English" in E.Ubahakwe (ed) varietiesand functions of English in Nigeria - Ibadan, NESA/OUP

Adetugbo, A. (1977) "Nigerian English: fact or fiction” in Lagos Notes and Records, vol. vi, pp. 128-141

- - - (1979) “Appropriateness and Nigerian English” in E. Ubahakwe (ed) varieties and functions of English in Nigeria Ibadan, NESA/OUP

- - - (1984) The English language in the Nigerian experience - Inaugural Lecture, Lagos University Press 
Akere, F. (1982) "Socioculuiral constraints and the emergence of a standard Nigerian English". in J. B. Pride (ed.) (1982) New Englishies; Rowley, Penn: Newbury House.

- - (2004) "Nigerian English in sociolinguistic perspective: users, uses and emerging varieties" in Nigerian English: influences and characteristics. A.B.K. Dadzie and Segun Awonusi (eds.), Lagos. Concept Publications

Ananda, S. (2009) "Error analysis: a pragmatic approach"

http://www.thdl.org/texts/reprints/contributions/CNAS06020/.pdf retrieved on 10 January, 2012.

Awonusi, V. O. (1985) "Sociolinguistic variation in Nigerian English," unpublished Ph.D thesis, University of London.

- - (2004) "The English language in a global context" in A.B.K. Dadzie and Segun Awonusi (eds.), Nigerian English: influences and characteristics. Lagos. Concept Publications.

Awonusi, S. \& Babalola, E. A. (eds) (2004) The domestication of English in Nigeria a Festschrift for Abiodun Adetugbo at 65, Lagos, University of Lagos Press.

Bamgbose, A. (1971) "The English language in Nigeria" in J. Spencer (ed) the English language in West AfricaLondon, Longman.

Bamgbose, A., Banjo, A., Thomas, A. (eds) (1993) New Englishes: a West African perspective, Ibadan Nigeria, Mosuro Printers.

Berelson, B. (1952) Content analysis in communication research. New York: Free Press.

Chomsky, N. (1957) Syntatic structures. The Hague: Mouton.

- - - (1965) Aspects of the theory of syntax. Cambridge. MA. MIT Press.

Corder, S. P. (1967) "The significance of learners error" In Jack Richards (ed) error analysis: perspectives on second language acquisition. London. Longman

Crystal D. (1997) The Cambridge encyclopedia of language, second edition, Cambridge, Cambridge University Press.

Dadzie A. B. K. (2004) "The concept of Nigerian English" in Nigerian English: influences and characteristics. A.B.K. Dadzie and Segun Awonusi (eds.), Lagos. Concept Publications

Darus, S. (2009) "Error analysis of the written essays of secondary school students in Malaysia: a case study" European Journal of Social Sciences - Vol. 8, number 3

Dulay, H. and Burt, M. (1974) "Errors and strategies in child second language acquisition" Tesol Quaterly, 129-136. Grieve, D. G. (1966) English language examining. Lagos: West African Examinations Council

Israel, P. C. (2012). A lexico-syntactic analysis of errors in selected textbooks written by Nigerian authors. An unpublished $\mathrm{PhD}$ Thesis, University of Lagos

Jibril, M. (1979) "Regional variation in Nigerian spoken English" in Ebo Ubahakwe (ed. 1979) varieties and functions of English in Nigeria. Ibadan: African University Press \& Nigeria English Studies Association, pp. 43-53

Jowitt, D. (1991) Nigerian English usage: an introduction, Lagos, Longman, Nigerian PLC.

Kachru, B. B. (1982) "The pragmatics of non-native varieties of English," in Smith, L. E. (ed)

Ker, A. 2009 "Problems of the book industry and educational development in Nigeria: lessons for the $21^{\text {st }}$ century." retrieved on 7 April, 2009 from http:/www. unilorin.edu.ng/unilorin/journals/education

King-Aribisala, K. (2012) Destination freedom: vehicle, symbolism in black literature Nigeria, University of Lagos Press

Kujore, O. (1985) English usage: some notable Nigerian variations - Ibadan, Evans Brothers.

Obilade, T. (1984) "On the nativization of the English language in Nigeria" anthropological linguistics, 26(2). pp.170185 .

Okoro, O. (1980) "Lexical and syntactic deviations in the English of Igbo speakers: a study of freshmen English in two Nigerian universities". unpublished M. Phil thesis, University of Lagos.

- - - (1992) "Characterizing the lects of Nigerian English: a descriptive analysis of their syntax and lexis", unpublished Ph.D thesis, University of Lagos.

Olagoke, D. O. (1975) “An error analysis of the English of Lagos university students" unpublished Ph.D thesis. University of London.

- - (1981) "Lexical deviations in Nigerian English," in $J L A C, 3 \& 4$, pp. 3537.

Platt, J. H. \& Weber, M. L. Ho. (1982) The new Englishes, London, Routledge and Kegan Paul.

Pride, J. B. (1982) (ed). New Englishes, Rowley, Massachusetts, Newbury House.

Richards, J. C. (1971) "Error analysis and second language strategies" Language Science, 17,12-22 b.

Spencer, J. (1971) (ed) The English language in West Africa, London, Longman.

Timothy-Asobele, S. J. (2007) Misunderstanding too often leads to war: translators and interpreters as peace makers, Nigeria, University of Lagos Press.

Ubahakwe, E. (1979) Varieties and functions of English in Nigeria, (ed). Ibadan, NESA / OUP. 